\title{
QUALITY AND SENSORY EVALUATIONS OF TEMPE PREPARED FROM VARIOUS PARTICLE SIZES OF LUPIN BEANS
}

\author{
[Evaluasi Sensorik dan Kualitas Tempe dari Kacang Lupin Berbagai Ukuran Partikel]
}

\author{
Sri Priatni ${ }^{1)^{*}}$, Anastasia F. Devi1), Leonardus B.S. Kardono ${ }^{1.3)}$ and Vijay Jayasena2) \\ 1) Research Center for Chemistry, Indonesian Institute of Sciences (LIPI), Bandung, Indonesia \\ 2) School of Public Health, Curtin University, Perth, WA, Australia \\ 3) International Center for Interdisciplinary and Advanced Research - LIPI, Jakarta, Indonesia
}

Accepted March 27th $2013 /$ Approved December $18^{\text {th }} 2013$

\begin{abstract}
Tempe is an Indonesian fermented soy bean, produced by using mainly Rhizopus oligosporus. Diversification of tempe raw materials is required for better food security, e.g., using lupin. The potency of lupin bean has been studied as a substitute of soy in tempe production. Nutritionally, lupin bean offers additional advantages over soy bean, i.e., it has a lower level of many anti-nutritional factors (ANFs) but contains higher protein (32-36\%) than most pulses. The objectives of this study were to select the most suitable lupin bean from different particle sizes for tempe production and to characterize the quality of lupin tempe. In this study, the lupin tempe samples were analyzed for moisture content, firmness, aroma, and the total count of colony after 1 and 2 days of fermentation. Sensory evaluation was conducted by 17 Indonesian untrained panelists (hedonic) in three different days. The data were evaluated statistically using General Linear Model (GLM) and Tukey's Honest Significant Difference (HSD). Results showed that the moisture content of lupin tempe ranged from 60 to $66 \%$, higher than that of soy tempe (58.90\%). Meanwhile, the firmness of lupin tempe was between 21.38-30.89 N. Mostly, tempes which were produced from $\leq 50 \%$ of particles sized $\geq 5 \mathrm{~mm}$ (L3, L5 and L6) exhibited poor quality in terms of firmness and aroma. The mean of total count of colony in lupin tempe were 3.0x104 CFU/g, lower than that of soy tempe $\left(218 \times 10^{3} \mathrm{CFU} / \mathrm{g}\right)$, indicating a slower growth of mycelia on lupin beans. However, the overall acceptability of lupin tempe which was prepared from whole beans ( $L 4$ and $L 7$ ) was not significantly different from that of soy tempe. Based on these quality and sensory tests, lupin tempe using whole lupin beans was recommended for substitute of soy bean in tempe production.
\end{abstract}

Keywords: lupin, tempe, quality, sensory

\begin{abstract}
ABSTRAK
Tempe merupakan produk fermentasi kedelai dari Indonesia yang dihasilkan melalui pertumbuhan kapang Rhizopus oligosporus. Diversifikasi bahan baku tempe untuk ketahanan pangan yang lebih baik, misalnya menggunakan lupin. Kacang lupin telah dipelajari potensinya sebagai bahan alternatif kedelai dalam produksi tempe. Secara nutrisi, kacang lupin memiliki kelebihan dibandingkan kedelai, antara lain memiliki faktor anti nutrisi yang lebih rendah tetapi mengandung protein lebih tinggi (32-36\%) dibandingkan kebanyakan kacang-kacangan. Tujuan dari penelitian ini adalah untuk menyeleksi ukuran partikel lupin yang paling sesuai dari berbagai ukuran partikel untuk produksi tempe, sehingga kualitas tempe lupin dapat ditingkatkan. Dalam penelitian ini, analisa terhadap tempe lupin meliputi kadar air, kekompakan (tekstur), aroma, dan angka kapang total setelah 1 dan 2 hari fermentasi. Uji sensori (hedonik) dilakukan oleh 17 panelis tidak terlatih berbangsa Indonesia dilakukan dalam 3 hari yang berbeda. Data uji sensori dianalisia secara statistik menggunakan General Linear Model (GLM) dan Tukey's Honest Significant Difference (HSD). Hasil analisa menunjukkan kadar air tempe lupin berkisar antara 60 sampai 66\%, lebih tinggi daripada tempe kedelai (58.90\%). Sementara itu, tekstur tempe lupin berkisar antara 21.38-30.89 N. Ditinjau dari tekstur dan aroma, tempe yang diproduksi dari campuran kacang lupin dengan proporsi ukuran partikel lebih dari $5 \mathrm{~mm}$ sebanyak $\leq 50 \%$ (L3, L5 dan L6) secara umum menunjukkan kualitas yang rendah. Total angka koloni tempe lupin adalah $3.0 \times 10^{4} \mathrm{CFU} / \mathrm{g}$, lebih rendah daripada jumlah koloni pada tempe kedelai $\left(2.2 \times 10^{5} \mathrm{CFU} / \mathrm{g}\right)$. Hal ini mengindikasikan pertumbuhan miselia pada kacang lupin lebih lambat daripada pertumbuhannya pada kedelai. Namun demikian, secara keseluruhan penerimaan panelis terhadap tempe dari kacang lupin utuh (L4 dan L7), tidak berbeda nyata dengan tempe kedelai. Berdasarkan uji sensori dan kualitas, tempe lupin dari sampel kacang utuh lupin dapat direkomendasikan sebagai pengganti kedelai dalam produksi tempe.
\end{abstract}

Kata kunci: kualitas, lupin, sensori, tempe

\section{INTRODUCTION}

Lupinus is a large genus of legumes which is wide-spread growing accros the world. Amongst lupin species, Lupinus angustifolius is the most distributed one. It requires acidic, well-

*Corresponding Author:

E-mail: sripriatni@yahoo.com; Phone: +62-222503051 drained, non-calcareous, and light-to-medium textured soil (Rumiyati et al. 2012, Wolko et al. 2011). Australian sweet lupin (ASL), L. angustifolius, is a high protein legume with similar protein quality to that of soy. Since its protein comprises essential amino acids, it becomes a suitable ingredient for enriching wheat flour for obtaining a balanced amino acid profile. Its low alkaloid content $(<15 \mathrm{mg} / 100 \mathrm{~g})$ ensures its safety for human diet (Jayasena et al. 2009, 2011). Sweet lupin is low 
in starch content and have low energy and glycemic index (GI) values. Lupin has been studied as a substitute for soy in tempe production by Fudiyansyah et al. (1995). The study shows that lupin bean cotyledons (splits) are suitable to substitute soybean in the laboratory scale production of lupin tempe. The lupin tempe is acceptable to a mixed group of Indonesians and Australians.

Research on utilization of sweet lupin for human foods can be classified into three groups: (1) the use of the whole grain or kernels as a soy substitute in traditional fermented and nonfermented Asian foods such as tempe and tofu, respectively; (2) the blending of lupin kernel flours with wheat flour in order to increase the fiber and protein content, for example for biscuit and pasta production; (3) the incorporation of lupin protein and fiber fractions to add food functionality (Jayasena et al. 2010; Hall and Johnson, 2004; Sweetingham and Kingwell, 2008). Although the studies show good sensorial acceptibility, there are a limited number of lupin based or lupin containing food products available in Australian or Asian markets. Amongst those products, Australian customers may find breads, muffins, pasta, and biscuits, which are most likely made from the blending of wheat and whole lupin kernel flours (Sweetingham and Kingwell, 2008).

Tempeh is an Indonesian fermented food made from soybeans that have been soaked and cooked to soften them (Babu et al. 2009). During tempe production, cooked and dehulled soybean cotyledons (which are acidified through spontaneous lactic acid fermentation during soaking in tropical regions, or by the addition of lactic acid or vinegar) are well drained, inoculated with the spores of Rhizopus oligosporus mold, packed into perforated containers (polyethylene bags or banana leaves), and incubated at $30-31^{\circ} \mathrm{C}$ for approximately 24 $\mathrm{h}$, until the beans are compactly bound by the mycelia (Shurtleff and Aoyagi, 2007). Rhizopus oligosporus is the dominant tempe mold although other molds, such as R. oryzae and Mucor spp, possibly contribute to the flavour, texture, or nutritive value (Babu et al. 2009). The fungal extracellular enzymes diffuse and degrade the solid substrate into soluble components during fermentation. These enzymes are excreted into the bean mass to facilitate the chemical changes during tempe fermentation (Varzakas, 1998).

Tempe manufacturing in Indonesia evolves with the availability of various beans or legumes. Minor indigenous tempe production includes okara tempe (tempe gembus), soybean-hulls tempe, peanut press cake tempe (tempe bungkil kacang), the coconut press-cake tempe (tempe bongkrek or tempe bungkil kelapa, which is occasionally poisonous if the pathogenic aerobic bacterium Pseudomonas cocovenenans grow on it and produce toxic colorless bongkrek acid), velvetbean tempe (tempe benguk), leucaena tempe (tempe lamtoro), mung bean tempe (tempe kacang hijau), mung bean pulp tempe, barley tempe and some other minor nonsoy tempe (Shurtleff and Aoyagi, 2007; Feng et al. 2007b). The interest to explore the potency of new seeds and grains for tempe production has been started since the late 1970s, for example with winged bean, jackbean, chickpea, kidneybean, and lupin (Nout and Kiers, 2005). In the case of lupin tempe, Jayasena (2009) investigated the possibilities of lupin as a source of tempe production. The preparation of lupin tempe has been developed effectively and efficiently. In addition, $R$ oligosporus also gives a positive contribution to the detoxification of lupin beans (Ortega-David and Rodríguez-Stouvenel, 2013).

The growth rate of Rhizopus oligosporus is limited by oxygen availability. Oxygen penetrates through the actively respiring biomass to reach the interior of particles and then diffuses through the aqueous phase within the substratum. However, the porosity of substrates affects degradation process. In the case of bulk beans with low porosity, the degradation occurs at the outer surface of the bulk mass whereas bulk beans with high porosity experience degradation inside the structure and the water soluble fragments will diffuse out (Varzakas, 1998; Bavia et al. 2012).

The objectives of this study were to select the suitable lupin beans for production of lupin tempe as a substitute of ordinary soy tempe and to improve the quality of lupin tempe. In order to obtain these purposes, the quality of fresh lupin tempe prepared from different particle sizes was evaluated in terms of its moisture content, firmness, aroma, and the total count of colony.

\section{MATERIALS AND METHODS}

\section{Materials}

Dehulled lupin bean (Lupinus angustifolius) samples were obtained from Perth, WA, Australia. They were different in particle sizes. The particle size distribution was determined using Tyler standard sieves (Ohio, United States) and the result is presented as Table 1. The samples were coded as samples L1 to L8. Soy bean was obtained from traditional market in Bandung, Indonesia. Tempe inoculums, mainly $R$. oligosporus, was prepared by Research Center for Chemistry, Indonesian Institute of Sciences (LIPI)

\section{Preparation of lupin tempe}

Dried dehulled lupin beans were washed with cold tap water and boiled for $30 \mathrm{~min}$. Separately, lupin and soybeans were soaked overnight in water containing acetic acid $(\mathrm{pH} \approx 4.0)$ at volume of 3.5 times of the bean weights. The beans were subsequently rewashed and drained prior to steamed, which the latter was carried out for $30 \mathrm{~min}$. The cooked beans were cooled to about $37^{\circ} \mathrm{C}$ and allowing steam to escape from the beans. The cooled lupin beans were mixed and inoculated with $0.5 \%$ of $R$. oligosporus starter and placed in perforated clear plastic bags. The packages were incubated at $30^{\circ} \mathrm{C}$ for $24 \mathrm{~h}$ and then transferred to room temperature for the next $24 \mathrm{~h}$, thus making the total time for fermentation $48 \mathrm{~h}$.

\section{Moisture content analysis}

The fresh chopped tempe sample $(2 \mathrm{~g})$ was accurately weighted in an uncovered dry moisture dish and dried in an oven at $105^{\circ} \mathrm{C}$. The sample was removed from the oven every 3 $\mathrm{h}$ and cooled in a desiccator for $2 \mathrm{~h}$ to reach room temperature. The sample was then weighed until a constant weight was achieved. Once a constant weight was achieved, the moisture content of the sample was calculated. 


\section{Firmness test}

The firmness test was carried out using a Mechanical Fruit Firmness Testers FT 327 QA supplies (Virginia, United States). The cylindrical tempe samples were prepared with the same size (diameter $\pm 5 \mathrm{~cm}$, thickness $\pm 3 \mathrm{~cm}$ ). The sample was held in the left hand, against the plunger of the penetrometer. The unit for firmness was reported as Newton ( $k g f \times 9.807)$.

\section{Total count of colony}

Fresh tempe sample of $0.1 \mathrm{~g}$ was diluted in $10 \mathrm{~mL}$ of sterile aqua containing $0.1 \%$ of Tween 80 . The suspension was mixed and diluted to $10^{-5}$ dilution serials. The diluted sample $(1 \mathrm{~mL})$ was placed in each sterile petri dish, in which the liquid potato dextrose agar (PDA) was added and slowly mixed. After the medium was solidified, petri dishes were incubated overnight at $30^{\circ} \mathrm{C}$. The growth of fungal colonies was counted directly.

\section{Preparation of fried tempe}

The sensory evaluation was applied to fried tempe samples. The preparation of fried tempe was according to a method published in Iskandar and Priatni (2008). Tempe samples in cylindrical shape were sliced with a thickness of $1 \mathrm{~cm}$. The sliced samples were then marinated in a salt solution $(1 \% \mathrm{w} / \mathrm{v}$ $\mathrm{NaCl}$ in water) for 15 min prior to deep frying in palm oil $\left( \pm 160^{\circ} \mathrm{C}\right)$ for $5-10 \mathrm{~min}$. The fried tempe samples were assessed immediately by untrained panelists.

\section{Design of experiment for sensory evaluation}

The hedonic test was conducted in three days, with 17 Indonesian untrained panelists were asked to test 6 samples of fried tempe ( 5 samples of selected lupin tempe and 1 sample of soy tempe). Three samples of lupin tempes were excluded from sensorial evalution because of the failure during fermentation process (indicated as 'not fresh' in Table 1). The panelists assessed the fried samples in terms of appearance, taste, texture, and overall acceptability.

Table 1. The average particle size of lupin bean samples

\begin{tabular}{cc}
\hline Sample No. & Particle Size $\geq 5 \mathrm{~mm}$ (Average) \\
\hline 1 & $100 \%$ \\
2 & $48 \%$ \\
3 & $39 \%$ \\
4 & $100 \%$ \\
5 & $50 \%$ \\
6 & $40 \%$ \\
7 & $100 \%$ \\
8 & $53 \%$ \\
\hline
\end{tabular}

\section{Statistic evaluation}

The statistical data analysis was conducted using General Linear Model (GLM), with factors comprises of replications, times (days), and lupin/soy samples. After the GLM analysis was conducted, the next step was to calculate the Tukey's HSD. Then, a pair wise comparison was done to each mean of responses at $5 \%$ level of significance.

\section{RESULTS AND DISCUSSION}

Lupin has been explored as a soy bean substitute in traditional fermented foods such as tempe and soy sauce. The present study investigated lupin tempe prepared through solid state fermentation method on eight samples of different particle sizes of lupin beans The physical and chemical properties (moisture content and firmness), aroma, and total count of colony of lupin tempe are shown in Table 2.

Table 2. The average values of soy and lupin tempe quality after fermentation for $24 \mathrm{~h}$ at $30^{\circ} \mathrm{C}$ and additional $24 \mathrm{~h}$ at room temperature (in total was $48 \mathrm{~h}$ fermentation)

\begin{tabular}{|c|c|c|c|c|}
\hline $\begin{array}{l}\text { Tempe } \\
\text { Sample }\end{array}$ & $\begin{array}{c}\text { Moisture } \\
\text { Content (\%) }\end{array}$ & $\begin{array}{c}\text { Firmness* } \\
\text { Newton }\end{array}$ & $\begin{array}{c}\text { Total Mold } \\
\text { Count } \\
\text { (CFU x 103/g) }\end{array}$ & Aroma \\
\hline Soy $(48 \mathrm{~h})$ & $58.90 \pm 1.55$ & $32.36 \pm 2.45$ & $218 \pm 5$ & fresh \\
\hline L 1 (24 h) & $63.37 \pm 1.48$ & $22.70 \pm 0.15$ & $16 \pm 3$ & fresh \\
\hline$(48 \mathrm{~h})$ & $60.71 \pm 2.34$ & $26.77 \pm 5.88$ & $35 \pm 3$ & fresh \\
\hline L 2 (24 h) & $65.07 \pm 0.95$ & $21.77 \pm 0.49$ & $12 \pm 2$ & fresh \\
\hline$(48 \mathrm{~h})$ & $63.33 \pm 0.66$ & $29.57 \pm 0.83$ & $29 \pm 2$ & fresh \\
\hline L 3 (24 h) & $66.68 \pm 0.54$ & $21.38 \pm 0.49$ & $10 \pm 4$ & fresh \\
\hline$(48 \mathrm{~h})$ & $65.40 \pm 0.56$ & $22.70 \pm 2.79$ & $28 \pm 8$ & not fresh \\
\hline L 4 (24 h) & $61.76 \pm 0.0$ & $23.68 \pm 1.81$ & $11 \pm 3$ & fresh \\
\hline$(48 \mathrm{~h})$ & $60.25 \pm 2.55$ & $30.89 \pm 3.43$ & $32 \pm 8$ & fresh \\
\hline L 5 (24 h) & $64.11 \pm 0.66$ & $22.70 \pm 0.83$ & $8 \pm 2$ & fresh \\
\hline$(48 \mathrm{~h})$ & $62.09 \pm 0.09$ & $24.37 \pm 3.09$ & $27 \pm 8$ & not fresh \\
\hline L 6 (24 h) & $65.35 \pm 0.08$ & $23.68 \pm 2.11$ & $5 \pm 1$ & fresh \\
\hline$(48 \mathrm{~h})$ & $63.56 \pm 2.27$ & $25.35 \pm 1.13$ & $32 \pm 0$ & not fresh \\
\hline L 7 (24 h) & $62.51 \pm 0.81$ & $24.17 \pm 2.30$ & $10 \pm 5$ & fresh \\
\hline$(48 \mathrm{~h})$ & $61.07 \pm 2.95$ & $30.74 \pm 5.25$ & $22 \pm 0$ & fresh \\
\hline L 8 (24 h) & $63.01 \pm 0.08$ & $24.03 \pm 2.45$ & $13 \pm 8$ & fresh \\
\hline$(48 \mathrm{~h})$ & $61.90 \pm 1.76$ & $30.2 \pm 3.43$ & $29 \pm 4$ & fresh \\
\hline
\end{tabular}

$\left(^{*}\right)$ statistically not significant $(p<0.05)$ for all $48 \mathrm{~h}$ fermentation samples (one way ANOVA)

The moisture contents of lupin tempe samples ranged from 60 to $66 \%$, higher than that of soy tempe $(58.90 \%)$. According to The National Standardization Agency of Indonesian (BSN) $3144: 2009$, the maximum moisture content of soy tempe is $65 \%$. The higher water retention of lupin tempe is most likely due to lupin's high water-holding capacity $\left(7.1 \mathrm{~g} \mathrm{H}_{2} \mathrm{O} / \mathrm{g}\right)$ as it contains crude fiber (Sujak et al. 2006).

The observations showed that the firmness of lupin tempe after $48 \mathrm{~h}$ fermentation was higher, in comparison to those obtained after $24 \mathrm{~h}$ fermentation (Table 2). Fermentation time of tempe production influences the bioactive compounds and consequently contributes to the quality of tempe (Chang et al. 2009; Roubos-van den Hil et al. 2010). Handoyo and Morita (2006) report that it requires approximately $24 \mathrm{~h}$ for achieve a complete fermentation of soybean. This ensures an even growth of mycelia both in the particles and in the gaps among each soybean grains. They report the textural property i.e. softness, modulus of elasticity and detaching-mycelia value of $48 \mathrm{~h}$ fermented soybean were significantly higher $(p<0.05)$ than those of other fermentation lengths. As a result, the $24 \mathrm{~h}$ fermented soybean was softer and had a compact form. However, after 48 $\mathrm{h}$ mycelia were overgrown and had stronger networked of mycelia among soybean grains. Moreover, the moisture content 
is also critical for tempe quality since it significantly influences firmness and shelf life. In this study, the firmness of lupin tempe was between 21.38-30.89 $\mathrm{N}$. The tempe fermentation was carried out subsequently for total fermentation length of $48 \mathrm{~h}$. The first $24 \mathrm{~h}$ was to initiate the growth of $R$. oligosporus mycelia which has an optimum temperature at $30^{\circ} \mathrm{C}$, and the temperature should be lower at the second $24 \mathrm{~h}$, to avoid the mass from overheating that inhibit the growth of mycelia. Based on statistical analysis of lupin tempe (Table 2), the firmness of lupin tempe after $48 \mathrm{~h}$ fermentation (L2, L4, L7 and L8) was significantly different $(p<0.05)$ from lupin tempe after $24 \mathrm{~h}$ fermentation. Mostly, tempe produced from the mixture of lupin beans with particle size less than $5 \mathrm{~mm}$ at proportion of $\geq 50 \%$ (L3, L5 and L6) exhibited low tempe quality.

Particle sizes of lupin beans contributed to the quality of lupin tempe, as shown by lupin tempe prepared from 100\% whole beans (L4 and L7). Both samples showed the highest firmness amongst the other lupin tempes. A previous study indicated that incorporation of lupin beans in tempe altered the moisture content and firmness (unpublished). Tempe samples with ratio of lupin and soybean at $60: 40$ had the moisture content of $60.57 \%$ and firmness of $36.87 \mathrm{~N}$ after $48 \mathrm{~h}$ fermentation. Based on these data, we suggested that the growth of $R$. oligosporus mycelia was influenced by total surface area of bean particles meaning also the particle size of beans and crude fiber content in fermenting media (bean particles) affected the growth of $R$. oligosporus mycelia.

During fermentation, volatile components were released due to enzymic activities. It was possible that particular legume types caused a distinctive aroma compared to others, i.e. the aroma of soy tempe was different from that of lupin tempe. It was also observed in our study that different aromas were released from each lupin tempe treatment. Table 2 shows data on aromas of tempe, prepared through $48 \mathrm{~h}$ fermentation of lupin beans. The lupin tempe made from particles $\geq 5 \mathrm{~mm}$ at proportion of $\leq 50 \%$ ( $L 3, L 5$ and $L 6)$ were not fresh. These samples had smaller particle sizes than those made from the whole beans (L4 and L7). A study by Handoyo and Morita (2006) shows that as the soy proteins are degrading during fermentation, the growth rate of $R$. oligosporus increases dramatically because it consumes the degradation products as nutrients (such as amino acids and low-molecular-weight peptides) for growing (Feng et al. 2007a). The mold then grows rapidly up to $24 \mathrm{~h}$ and enters a maturing process. We suggested that the enhanced degradation of protein by $R$. oligosporus occurred in lupin beans with smaller particle sizes because it had more surface areas for $R$. oligospourus to attach. This caused rapid protein degradation, thus more protein degradation products are available for the mold to grow. As a consequence, this led to the over-fermentation thus increased production of unpleasant volatile compounds (i.e. ammonia and small peptides).

The particle characteristics of lupin beans influenced the growth of $R$. oligosporus, which contributed to the quality of the final tempe products. As shown in Figure 1B, the lupin tempe was visually similar to soy tempe even the appearance of lupin tempe was more attractive due to the bright yellow colour of lupin kernels. The mycelia of $R$. oligosporus were capable of growing on both lupin and soy tempe substrates yet at different rates. After $48 \mathrm{~h}$ fermentation, the data of total count of colony showed that the colony number of lupin tempe samples were $\pm 30 \times 10^{3} \mathrm{CFU} / \mathrm{g}$. The growth of mycelia on lupin beans was slower than that on soy, as shown by seven-fold colony number of soy tempe $\left(218 \times 10^{3} \mathrm{CFU} / \mathrm{g}\right)$. We proposed that the hardness of lupin beans contributed to the lower growth of $R$. oligosporus. However, both lupin and soy tempe showed white mycelia and good in appearances. We suggested that the enzymic activities of $R$. oligosporus were influenced by the characteristics of beans during tempe fermentation.

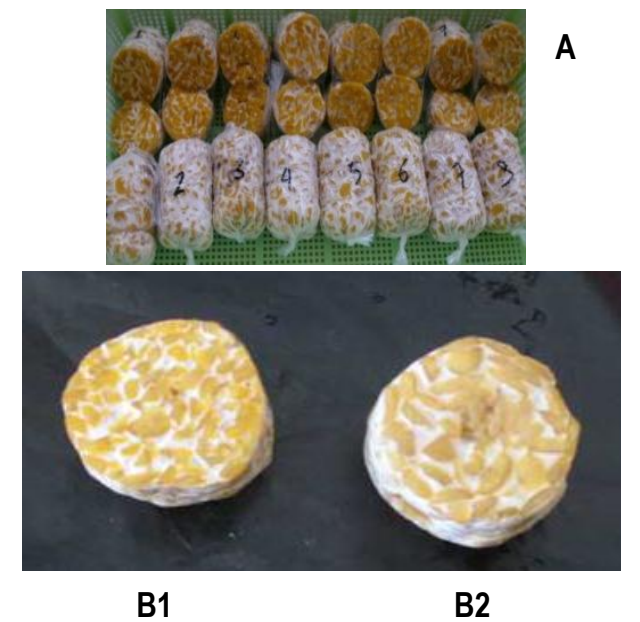

Figure 1. Lupin tempe samples (A) and a sliced lupin tempe (B1) in comparison to sliced soy tempe (B2) after fermentation for $24 \mathrm{~h}$ at $30^{\circ} \mathrm{C}$ and additional $24 \mathrm{~h}$ at room temperature (in total was $48 \mathrm{~h}$ fermentation)

The diffusion of fungal extracellular enzymes is very important for solid substrate fermentation (SSF). These enzymes were excreted into the bean mass to catalyze the chemical changes during fermentation of substrates concomitant with mold growth. On this stage, two important characteristics from mold growth need to take place for the fermented soybeans to become tempe, namely, the individual beans are bound into a solid cake by the mold mycelia and the soybeans become partially digested by the mold enzymes (Babu et al. 2009; Priatni and Iskandar, 2007; Haq and Mukhtar, 2004). After the growth declining, sporulation and ammonia production, due to protein breakdown, take place. Moreover, viability of $R$. oligosporus sporangiospores is also important for the application of stored starter cultures for tempe production (Thanh and Nout, 2004).

Based on the data of quality of lupin tempe, we selected five lupin samples (L1, L2, L4, L7 and L8) for sensory evaluation. Thus, the untrained panelists tested five fried lupin tempe and one fried soy tempe samples in terms of appearance, taste, texture, and overall acceptability. The data were evaluated statistically using GLM and Tukey's HSD. Statistic data obtained from this sensory evaluation was shown in Table 3.

The data in Table 3 shown that the appearance of lupin tempe prepared from $100 \%$ whole beans (L7) was scored as the best (7.265) amongst the samples, outnumbered soy tempe (6.333). Aroma and taste of this lupin tempe (6.647) was not 
significantly different from that of soy tempe (6.627). In the present research, the scores for texture of this lupin tempe product (6.176), was not significantly different from that of soy tempe (6.471). The overall acceptability of lupin tempe prepared from $100 \%$ whole beans (L7) was 6.588 , which was not significantly different from that of soy tempe (6.510). Our result is in agreement with an earlier sensory study of lupin tempe by Fudiyansyah (1995); a substitution of soybeans with lupin beans at level 50 to $100 \%$.

Table 3. Mean difference values data of lupin and soy tempe sensory evaluation

\begin{tabular}{ccccc}
\hline $\begin{array}{c}\text { Tempe } \\
\text { Sample }\end{array}$ & Appearance & $\begin{array}{c}\text { Aroma and } \\
\text { Taste }\end{array}$ & Texture & $\begin{array}{c}\text { Overall } \\
\text { Acceptability }\end{array}$ \\
\hline Soy & $6.333 \pm 0.255^{\mathrm{a}}$ & $6.627 \pm 0.288^{\mathrm{a}}$ & $6.471 \pm 0.282^{\mathrm{a}}$ & $6.510 \pm 0.285^{\mathrm{a}}$ \\
L1 & $6.500 \pm 0.175^{\mathrm{a}}$ & $5.853 \pm 0.227 \mathrm{~b}$ & $5.794 \pm 0.246^{\mathrm{bc}}$ & $6.000 \pm 0.215^{\mathrm{b}}$ \\
L2 & $6.980 \pm 0.149^{\mathrm{b}}$ & $5.588 \pm 0.279^{\mathrm{b}}$ & $6.059 \pm 0.253^{\mathrm{ac}}$ & $6.020 \pm 0.233^{\mathrm{b}}$ \\
L4 & $7.078 \pm 0.137^{\mathrm{b}}$ & $6.020 \pm 0.256^{\mathrm{b}}$ & $5.863 \pm 0.255^{\mathrm{bc}}$ & $6.078 \pm 0.227^{\mathrm{b}}$ \\
L7 & $7.265 \pm 0.111^{\mathrm{b}}$ & $6.647 \pm 0.222^{\mathrm{a}}$ & $6.176 \pm 0.202^{\mathrm{ac}}$ & $6.588 \pm 0.184^{\mathrm{a}}$ \\
L8 & $6.647 \pm 0.162^{\mathrm{a}}$ & $5.765 \pm 0.239^{\mathrm{b}}$ & $5.529 \pm 0.242^{\mathrm{b}}$ & $5.765 \pm 0.240^{\mathrm{b}}$ \\
\hline
\end{tabular}

$\mathrm{a}, \mathrm{b}, \mathrm{c}, \mathrm{d}$ the same index in the same column shows insignificant difference

\section{CONCLUSION}

Five out of eight various particle sizes of lupin beans were successfully fermented into lupin tempe, through fermentation process using $R$. oligosporus tempe inoculum. Based on the quality and sensory test of lupin tempe, the whole lupin beans (L7) was recommended to replace soybean in tempe production as the final tempe properties exhibited no significant differences to soy tempe in terms of aroma and taste, texture, and overall acceptability according to sensory evaluation, but its appearance was scored as more attractive.

\section{ACKNOWLEDGEMENT}

This research was supported by Natural Products, Food and Pharmaceuticals Division-Research Centre for Chemistry (LIPI) and Grain Foods Innovations Ltd, Australia.

\section{REFERENCES}

Aderibigbe EY, Osegboun AO. 2006. Acceptability of tempe among health workers in Ado-Ekiti, Nigeria. Pakistan J Nutr 5: 122-124. DOI: 10.3923/pjn.2006.122.124

Babu PD, Bhakyaraj R, Vidhyalakshmi R. 2009. A low cost nutritious food "tempe"- a review. World J Dairy Food Sci 4: 22-27.

Bavia ACF, da Silva CE, Ferreira MP, Leite RS, Mandarino JMG, Carřao-Panizzi MC. 2012. Chemical composition of tempe from soybean cultivars specially developed for human consumption. Ciênc Tecnol Aliment 32: 613-620. DOI: 10.1590/S0101-20612012005000085.

[BSN] Badan Standarisasi Nasional. 2009. Standar Nasional Indonesia: Tempe Kedelai. SNI 3144:2009. Badan Standarisasi Nasional.
Chang CT, Hsu CK, Chou ST, Chen YC, Huang FS, Chung YC. 2009. Effect of fermentation time on the antioxidant activities of tempe prepared from fermented soybean using Rhizopus oligosporus. Int J Food Sci Tech 44: 799-806. DOI: 10.1111/ j.1365-2621.2009.01907.x.

Feng XM, Larsen TO, Schnürer J. 2007ª Production of volatile compounds by Rhizopus oligosporus during soybean and barley tempe fermentation. Int J Food Microbiol 113: 133141. DOI: 10.1016/j.ijfoodmicro.2006.06.025.

Feng XM, Passoth V, Eklund-Jonsson C, Alminger ML, Schnürer J. 2007b. Rhizopus oligosporus and yeast cocultivation during barley tempe fermentation-Nutritional impact and real-time PCR quantification of fungal growth dynamics. Food Microbiol 24: 393-402. DOI: 10.1016/ j.fm.2006.06.007.

Fudiyansyah N, Petterson DS, Bell RR, Fairbrother AH. 1995. A nutritional, chemical and sensory evaluation of lupin (L.angustifolius) tempe. Int J Food Sci Tech 30: 297-305. DOI: 10.1111/j.1365-2621.1995.tb01378.x.

Hall RS, Johnson SK. 2004. Sensory acceptability of foods containing Australian sweet lupin (Lupinus angustifolius) flour. J Food Sci 69: snq92-97. DOI: 10.1111/j.13652621.2004.tb15520.x.

Handoyo T, Morita N. 2006. Structural and functional properties of fermented soybean (tempe) by using Rhizopus oligosporus. Int J Food Prop 9: 347-355. DOI: 10.1080/ 10942910500224746.

Haq I, Mukhtar H. 2004. Biosynthesis of proteases by Rhizopus oligosporus $\mathrm{IHS}_{13}$ in low-cost medium by solid-state fermentation. J Basic Microb 44: 280-287. DOI: 10.1002/ jobm.200410393.

Iskandar MI, Priatni S. 2008. Isoflavones aglicone of tempe Malang fried slices. Indonesian J Chem 8: 437-442.

Jayasena V. 2009. Lupin, is this next generation grain legume?. Food Rev Indo 4: 30-33.

Jayasena V, Chih HJ, Nasar-Abbas SM. 2011. Efficient isolation of lupin protein. Food Aust 63: 306-309.

Jayasena V, Khu WS, Nasar-Abbas SM. 2010. The development and sensory acceptability of lupin-based tofu. J Food Quality 33: 85-97. DOI: 10.1111/j.1745-4557.2009. 00290.X.

Nout MJR, Kiers JL. 2005. Tempe fermentation, innovation and functionality: update into the third millenium. J Appl Microbiol 98: 789-805. DOI: 10.1111/j.1365-2672.2004. 02471.x.

Ortega-David E, Rodríguez-Stouvenel A. 2013. Degradation of quinolizidine alkaloids of lupin by Rhizopus oligosporus. Appl Microbiol Biotechnol 97: 4799-4810. DOI: 10.1007/ s00253-013-4736-x.

Priatni S, Iskandar YM. 2007. Influences of tempe inoculums Rhizopus oligosporus and incubation temperature to the quality of soybean tempe. Majalah Teknol Indonesia 30: 5560.

Roubos-van den Hil PJ, Schols HA, Nout MJR, Zwietering MH, Gruppen H. 2010. First characterization of bioactive components in soybean tempe that protect human and 
animal intestinal cells against enterotoxigenic Escherichia coli (ETEC) infection. J Agr Food Chem 58: 7649-7656. DOI: $10.1021 /$ jf101379y.

Rumiyati, James AP, Jayasena V. 2012. Effect of germination on the nutritional and protein profile of Australian sweet lupin (Lupinus angustifolius L.). Food Nutr Sci 3: 621-626. DOI: 10.4236/fns.2012.35085.

Shurtleff B, Aoyagi A. 2007. History of Tempe, A Special Report on the History of Traditional Fermented Soy Foods. A Chapter from the Unpublished Manuscript, History of Soybeans and Soy Foods: 1100 B.C. to the 1980s. Soyinfo Center, Lafayette, California.

Sujak A, Kotlarz A, Strobel W. 2006. Compositional and nutritional evaluation of several lupin seeds. Food Chem 98: 711-719. DOI: 10.1016/j.foodchem.2005.06.036.
Sweetingham M, Kingwell R. 2008. Lupins - Reflections and Future Possibilities. Proceedings of the 12th International Lupin Conference, 14-18 Sept. Fremantle, Western Australia. International Lupin Association, Canterbury, New Zealand. ISBN 0-86476-153.

Thanh NV, Nout MJR. 2004. Dormancy, activation and viability of Rhizopus oligosporus sporangiospores. Int J Food Microbiol 92: 171-179. DOI: 10.1016/j.ijfoodmicro.2003. 09.008.

Varzakas T. 1998. Rhizopus oligosporus mycelial penetration and enzyme diffusion in soya bean tempe. Process Biochem 33: 741-747. DOI: 10.1016/S0032-9592(98)000442.

Wolko B, Clements JC, Naganowska B, Nelson NM, Yang H. 2011. Lupinus. A Chapter in Wild Crop Relatives: Genomic and Breeding Resources, Legume Crops and Forages. 153206. Springer-Verlag, Berlin. 